\title{
Assessing Sufficiency and Quality of Bandwidth for Public Libraries
}

Based on data collected as part of the 2006 Public Libraries and the Internet study, the authors assess the degree to which public libraries provide sufficient and quality bandwidth to support the library's networked services and resources. The topic is complex due to the arbitrary assignment of a number of kilobytes per second (kbps) used to define bandwidth. Such arbitrary definitions to describe bandwidth sufficiency and quality are not useful. Public libraries are indeed connected to the Internet and do provide public-access services and resources. It is, however, time to move beyond connectivity type and speed questions and consider issues of bandwidth sufficiency, quality, and the range of networked services that should be available to the public from public libraries. A secondary, but important issue is the extent to which libraries, particularly in rural areas, have access to broadband telecommunications services.

\section{T} he biennial Public Libraries and the Internet studies, conducted since 1994, describe public library involvement with and use of the Internet. ${ }^{1}$ Over the years, the studies showed the growth of public-access computing (PAC) and Internet access provided by public libraries to the communities they serve. Internet connectivity rose from 20.9 percent to essentially 100 percent in less than ten years; the average number of public access computers per library increased from an average of two to nearly eleven; and bandwidth rose to the point where 63 percent of public libraries have connection speeds of greater than $769 \mathrm{kbps}$ (kilobytes per second) in 2006. This dramatic growth, replete with related information technology challenges, occurred in an environment of challenges-among them budgetary and staffing - that public libraries face in maintaining traditional services as well as networked services.

One challenge is the question of bandwidth sufficiency and quality. The question is complex because typically an arbitrary number describes the number of kbps used to define "broadband." As will be seen in this paper, such arbitrary definitions to describe bandwidth sufficiency are generally not useful. The Federal Communications Commission (FCC), for example, uses the term "high speed" for connections of 200kbps in at least one direction. ${ }^{2}$ There are three problematic issues with this definition:

1. It specifies unidirectional bandwidth, meaning that a 200kbps download, but a much slower upload (e.g., 56kbps) would fit this definition;

2. Regardless of direction, bandwidth of 200kbps is neither high speed nor does it allow for a range of
Internet-based applications and services. This inadequacy will increase significantly as Internet-based applications continue to demand more bandwidth to operate properly.

3. The definition is in the context of broadband to the single user or household, and does not take into consideration the demands of a high-use multipleworkstation public-access context.

In addition to connectivity speed, there are many questions related to public library PAC and Internet access that can affect bandwidth sufficiency-from budget and sustainability, staffing and support, to services public libraries offer through their technology infrastructure, and the impacts of connectivity and PAC on the communities that libraries serve. One key question, however, is what is quality PAC and Internet bandwidth for public libraries? And, in attempting to answer that question, what are measures and benchmarks of quality Internet access? This paper provides data from the 2006 Public Libraries and the Internet study to foster discussion and debate around determining quality PAC and Internet access. ${ }^{3}$

Bandwidth and connectivity data at the library outlet or branch level are presented in this article. The bandwidth measures are not systemwide but rather at the point of service delivery in the branch.

\section{The bandwidth issue}

There are a number of factors that affect the sufficiency and quality of bandwidth in a PAC and Internet service context. Examples of factors that influence actual speed include:

- number of workstations (public-access and staff) that simultaneously access the Internet;

- provision of wireless access that shares the same connection;

- ultimate connectivity path-that is, a direct connection to the Internet that is truly direct, or one that goes through regional or other local hops (that may have aggregated traffic from other libraries or organizations) out to the Internet;

John Carlo Bertot (jbertot@fsu.edu) is the Associate Director of the Information Use Management and Policy Institute and Professor at the College of Information, Florida State University; and Charles R. McClure (cmcclure@ci.fsu.edu) is the Director of the Information Use Management and Policy Institute (www .ii.fsu.edu) and Francis Eppes Professor of Information Studies at the College of Information, Florida State University. 
- type of connection and bandwidth that the telecommunications company is able to supply the library;

- operations (surfing, e-mail, downloading large files, streaming content) being performed by users of the Internet connection;

- switching technologies;

- latency effects that affect packet loss, jitter, and other forms of noise throughout a network;

- local settings and parameters, known or unknown, that impede transmission or bog down the delivery of Internet-based content;

- range of networked services (databases, videoconferencing, interactive/real-time services) to which the library is linked;

- if networked, the speed of the network on which the public-access workstations reside; and

- general application resource needs, protocol priority, and other general factors.

Thus, it is difficult to precisely answer "how much bandwidth is enough" within an evolving and dynamic context of public access, use, and infrastructure.

Putting public-access Internet use into a more typical application-and-use scenario, however, may provide some indication of adequate bandwidth. For example:

- a typical three-minute digital song is $3 \mathrm{MB}$;

- a typical digital photo is about $2 \mathrm{MB}$; and

- a typical PowerPoint presentation is about 10MB.

If one person in a public library were to e-mail a PowerPoint presentation at the same time that another person downloaded multiple songs, and another was exchanging multiple pictures, even a library with a T1 line (1.5mbps-megabytes per second) would experience a temporary network slowdown during these operations. This does not take into account many other new highbandwidth-consuming applications such as CNN streaming-video channel; uploading and accessing content to a wiki, blog, or YouTube.com; or streaming content such as CBS's webcasting the 2006 NCAA basketball tournament.

An increasingly used technology in various settings is two-way Internet-based video conferencing. With an installed T1 line, a library could support two 512kbps or three $384 \mathrm{kbps}$ videoconferences, depending on the amount of simultaneous traffic on the network-which, in a public access context, would be heavy. Indeed, the 2006 Public Libraries and the Internet study indicated a near continuous use of public-access workstations by patrons (only 14.6 percent of public libraries indicated that they always had a sufficient number of workstations available for patron use).

Public libraries increasingly serve as access points to e-government services and resources, e.g., social services, disaster relief, health care. ${ }^{4}$ These services can require the simple completion of a Web-based form (low-bandwidth consumption) to more interactive services (high-bandwidth consumption). And, as access points to continuing education and online degree programs, public libraries need to offer adequate broadband to enable users to access services and resources that increasingly can depend on streaming technologies that consume greater bandwidth.

\section{Bandwidth and PAC in public libraries today}

As table 1 demonstrates, public libraries continue to increase their bandwidth, with 63.3 percent of public libraries reporting connection speeds of $769 \mathrm{kbps}$ or greater. This compares to 47.7 percent of public libraries reporting connection speeds of greater than $769 \mathrm{kbps}$ in 2004. There are disparities between rural and urban public libraries, with rural libraries reporting substantially fewer instances of connection speeds of greater than $1.5 \mathrm{mbps}$ in 2006 . On the one hand, the increase in connectivity speeds between 2004 and 2006 is a positive step. On the other, 16.1 percent of public libraries report that their connection speeds are insufficient to meet patron demands all of the time, and 29.4 percent indicate that their connection speeds are insufficient to meet patron demands some of the time. Thus, nearly half of public libraries indicate that their connection speeds are insufficient to meet patron demands some or all of the time.

In terms of public access computers, the average number of workstations that public libraries provide is 10.7 (table 2). Urban libraries have an average of 17.1 workstations, as compared to rural libraries, which report an average of 7.1 workstations.

\section{A closer look at bandwidth and PAC}

For the next sections, the data offer two key views for analysis purposes: (1) workstations-divided into libraries with ten or fewer public-access workstations and libraries with more than ten public-access workstations (given that the average number of public-access workstations in libraries is roughly ten); and (2) bandwidth-divided into libraries with $769 \mathrm{kbps}$ or less and libraries with greater than $769 \mathrm{kbps}$ (an arbitrary indicator of broadband for a public library context).

In looking across bandwidth and public-access workstations (table 3), overall 31.8 percent of public libraries have connection speeds of less than $769 \mathrm{kbps}$ while 63.3 percent have connection speeds of greater than $769 \mathrm{kbps}$. A majority of public libraries - 68.5 percent-have ten or fewer workstations, while 30.9 percent have more than ten workstations. In general, rural libraries have fewer workstations and lower bandwidth as compared to suburban and urban libraries. Indeed, 75.2 percent of urban 
Table 1. Public library outlet maximum speed of public-access Internet services by metropolitan status and poverty

\begin{tabular}{|c|c|c|c|c|c|c|c|}
\hline Maximum speed & \multicolumn{3}{|c|}{ Metropolitan status } & \multicolumn{4}{|c|}{ Poverty level } \\
\hline Less than 56kbps & $\begin{array}{l}0.7 \% \\
\pm 0.8 \% \\
(n=18)\end{array}$ & $\begin{array}{l}0.4 \% \\
\pm 0.6 \% \\
(n=17)\end{array}$ & $\begin{array}{l}3.7 \% \\
\pm 1.9 \% \\
(n=275)\end{array}$ & $\begin{array}{l}2.0 \% \\
\pm 1.4 \% \\
(n=245)\end{array}$ & $\begin{array}{l}2.7 \% \\
\pm 1.6 \% \\
(n=61)\end{array}$ & $\begin{array}{l}2.6 \% \\
\pm 1.6 \% \\
(n=5)\end{array}$ & $\begin{array}{l}2.1 \% \\
\pm 1.4 \% \\
(n=311)\end{array}$ \\
\hline 56kbps- 128kbps & $\begin{array}{l}2.5 \% \\
\pm 1.6 \% \\
(n=67)\end{array}$ & $\begin{array}{l}5.4 \% \\
\pm 2.3 \% \\
(n=264)\end{array}$ & $\begin{array}{l}15.2 \% \\
\pm 3.6 \% \\
(n=1,132)\end{array}$ & $\begin{array}{l}9.9 \% \\
\pm 3.0 \% \\
(n=1,237)\end{array}$ & $\begin{array}{l}9.5 \% \\
\pm 2.9 \% \\
(n=216)\end{array}$ & $\begin{array}{l}5.3 \% \\
\pm 2.2 \% \\
(n=10)\end{array}$ & $\begin{array}{l}9.8 \% \\
\pm 3.0 \% \\
(n=1,463)\end{array}$ \\
\hline 129kbps- 256kbps & $\begin{array}{l}2.7 \% \\
\pm 1.6 \% \\
(n=72)\end{array}$ & $\begin{array}{l}6.8 \% \\
\pm 2.5 \% \\
(n=332)\end{array}$ & $\begin{array}{l}11.1 \% \\
\pm 3.1 \% \\
(n=829)\end{array}$ & $\begin{array}{l}8.5 \% \\
\pm 2.8 \% \\
(n=1,067)\end{array}$ & $\begin{array}{l}7.3 \% \\
\pm 2.6 \% \\
(n=166)\end{array}$ & - & $\begin{array}{l}8.2 \% \\
\pm 2.8 \% \\
(n=1,233)\end{array}$ \\
\hline 257kbps-768kbps & $\begin{array}{l}9.1 \% \\
\pm 2.9 \% \\
(n=241)\end{array}$ & $\begin{array}{l}10.4 \% \\
\pm 3.1 \% \\
(n=504)\end{array}$ & $\begin{array}{l}13.4 \% \\
\pm 3.4 \% \\
(n=1,002)\end{array}$ & $\begin{array}{l}12.5 \% \\
\pm 3.3 \% \\
(n=1,557)\end{array}$ & $\begin{array}{l}8.4 \% \\
\pm 2.8 \% \\
(n=190)\end{array}$ & - & $\begin{array}{l}11.7 \% \\
\pm 3.2 \% \\
(n=1,747)\end{array}$ \\
\hline Don't know & $\begin{array}{l}1.9 \% \\
\pm 1.4 \% \\
(n=50)\end{array}$ & $\begin{array}{l}5.4 \% \\
\pm 2.3 \% \\
(n=263)\end{array}$ & $\begin{array}{l}5.7 \% \\
\pm 2.3 \% \\
(n=427)\end{array}$ & $\begin{array}{l}5.5 \% \\
\pm 2.3 \% \\
(n=685)\end{array}$ & $\begin{array}{l}2.1 \% \\
\pm 1.4 \% \\
(n=48)\end{array}$ & $\begin{array}{l}3.5 \% \\
\pm 1.8 \% \\
(n=6)\end{array}$ & $\begin{array}{l}4.9 \% \\
\pm 2.2 \% \\
(n=739)\end{array}$ \\
\hline
\end{tabular}

Weighted missing values, $n=1,497$

libraries with fewer than ten workstations have connection speeds of greater than $769 \mathrm{kbps}$, as compared to 45.2 percent of rural libraries.

When examining PAC capacity, it is clear that public libraries have capacity issues at least some of the time in a typical day (tables 4 through 6). Only 14.6 percent of public libraries report that they have sufficient numbers of workstations to meet patron demands at all times (table 6), while nearly as many, 13.7 percent, report that they consistently are unable to meet patron demands for public-access workstations (table 4). A full 71.7 percent indicate that they are unable to meet patron demands during certain times in a typical day (see table 5). In other words, 85.4 percent of public libraries report that they are unable to meet patron demand for public-access workstations some or all of the time during a typical day-regardless of number of workstations available and type of library.

The disparities between rural and urban libraries are notable. In general, urban libraries report more difficulty in meeting patron demands for public-access workstations. Of urban public libraries, 27.8 percent report that they consistently have difficulty in meeting patron demand for workstations, as compared to 11.0 percent of suburban and 10.6 percent of rural public libraries (table 4). By contrast,
Table 2. Average number of public library outlet graphical publicaccess Internet terminals by metropolitan status and poverty*

\begin{tabular}{lllll} 
& \multicolumn{4}{c}{ Poverty level } \\
\cline { 2 - 5 } $\begin{array}{l}\text { Metropolitan } \\
\text { status }\end{array}$ & Low & Medium & High & Overall \\
Urban & & & & \\
Suburban & 14.7 & 20.9 & 30.7 & 17.9 \\
Rural & 12.8 & 9.7 & 5.0 & 12.6 \\
Overall & 7.1 & 6.7 & 8.1 & 7.1 \\
\hline
\end{tabular}

* Note that most library branches defined as "high poverty" are in general part of library systems with multiple branches and not single building systems. By and large, library systems connect and provide PAC and Internet services systemwide.

6.6 percent of urban libraries report sufficient workstations to meet patron demand all the time as compared to 18.9 percent of rural libraries (table 6).

When reviewing the adequacy of speed of connectivity data by the number of workstations, bandwidth, and metropolitan status, a more robust and descriptive pic- 
Table 3. Public library public-access workstations and speed of connectivity by metropolitan status

\begin{tabular}{l|ll|ll|ll|} 
& \multicolumn{3}{|c|}{ Rural } & \multicolumn{2}{c}{ Suburban } & \multicolumn{2}{c}{ Urban } \\
& LT769kbps & GT769KBPS & LT769kbps & GT769KBPS & LT769kbps & GT769KBPS \\
\hline 10 or fewer & $48.4 \%$ & $45.2 \%$ & $30.1 \%$ & $63.2 \%$ & $21.6 \%$ & $75.2 \%$ \\
workstations & $n=2,929$ & $n=2,737$ & $n=891$ & $n=1,872$ & $n=269$ & $n=937$ \\
More than 10 & $22.0 \%$ & $75.5 \%$ & $12.0 \%$ & $85.1 \%$ & $9.6 \%$ & $89.8 \%$ \\
workstations & $n=307$ & $n=1,053$ & $n=225$ & $n=1,595$ & $n=130$ & $n=1,221$ \\
Total & $43.4 \%$ & $50.9 \%$ & $23.0 \%$ & $71.6 \%$ & $15.1 \%$ & $83.0 \%$ \\
\hline
\end{tabular}

Missing: $7.6 \%(n=1,239)$

Table 4. Fewer public library public-access workstations than patrons wishing to use them by metropolitan status

\begin{tabular}{lllll}
\hline & Rural & Suburban & Urban & Total \\
\hline 10 or fewer & $10.5 \%$ & $10.8 \%$ & $23.6 \%$ & $12.1 \%$ \\
workstations & $\mathrm{n}=681$ & $\mathrm{n}=339$ & $\mathrm{n}=300$ & $\mathrm{n}=1,321$ \\
More than 10 & $10.8 \%$ & $11.4 \%$ & $31.2 \%$ & $16.9 \%$ \\
workstations & $\mathrm{n}=158$ & $\mathrm{n}=220$ & $\mathrm{n}=430$ & $\mathrm{n}=808$ \\
& $10.6 \%$ & $11.0 \%$ & $27.8 \%$ & $13.7 \%$ \\
Total & $\mathrm{n}=845$ & $\mathrm{n}=562$ & $\mathrm{n}=748$ & $\mathrm{n}=2,157$ \\
\hline
\end{tabular}

Missing: $2.9 \%(n=473)$

Table 5. Fewer public library public-access workstations than patrons wishing to use them at certain times during a typical day by metropolitan status

\begin{tabular}{lllll}
\hline & Rural & Suburban & Urban & Total \\
\hline 10 or fewer & $68.8 \%$ & $74.5 \%$ & $69.1 \%$ & $70.5 \%$ \\
workstations & $\mathrm{n}=4,444$ & $\mathrm{n}=2,347$ & $\mathrm{n}=880$ & $\mathrm{n}=7,670$ \\
More than 10 & $78.1 \%$ & $80.2 \%$ & $62.8 \%$ & $74.5 \%$ \\
workstations & $\mathrm{n}=1,139$ & $\mathrm{n}=1,548$ & $\mathrm{n}=866$ & $\mathrm{n}=3,553$ \\
Total & $70.5 \%$ & $76.7 \%$ & $65.6 \%$ & $71.7 \%$ \\
& $\mathrm{n}=5,605$ & $\mathrm{n}=3,905$ & $\mathrm{n}=1,764$ & $\mathrm{n}=11,273$ \\
\hline
\end{tabular}

Missing: $2.9 \%(n=473)$

Table 6. Sufficient public library public-access workstations available for patrons wishing to use them by metropolitan status

\begin{tabular}{lllll}
\hline & Rural & Suburban & Urban & Total \\
\hline 10 or fewer & $20.6 \%$ & $14.7 \%$ & $7.4 \%$ & $17.4 \%$ \\
workstations & $\mathrm{n}=1,331$ & $\mathrm{n}=464$ & $\mathrm{n}=94$ & $\mathrm{n}=1,889$ \\
More than 10 & $11.0 \%$ & $8.4 \%$ & $6.0 \%$ & $8.5 \%$ \\
workstations & $\mathrm{n}=161$ & $\mathrm{n}=163$ & $\mathrm{n}=83$ & $\mathrm{n}=406$ \\
& $18.9 \%$ & $12.3 \%$ & $6.6 \%$ & $14.6 \%$ \\
Total & $\mathrm{n}=1,501$ & $\mathrm{n}=627$ & $\mathrm{n}=177$ & $\mathrm{n}=2,304$ \\
\hline
\end{tabular}

Missing: $2.9 \%(n=473)$

ture emerges. While overall, 53.5 percent of public libraries indicate that their connection speeds are adequate to meet demand, some parsing of this figure reveals more variation (tables 7 through 10):

- Libraries with connection speeds of $769 \mathrm{kpbs}$ or less are more likely to report that their connection speeds are insufficient to meet patron demand at all times, with 24.0 percent of rural libraries, 25.8 percent of suburban libraries, and 25.4 percent of urban libraries so reporting (table 7).

- Libraries with connection speeds of $769 \mathrm{kpbs}$ or less are more likely to report that their connection speeds are insufficient to meet patron demand at some times, with 35.0 percent of rural libraries, 38.1 percent of suburban libraries, and 53.4 percent of urban libraries so reporting (table 8).

- Libraries with connection speeds of greater than $769 \mathrm{kbps}$ also report bandwidth-sufficiency issues, with 12.0 percent of rural libraries, 10.5 percent of suburban libraries so reporting; and 14.0 percent of urban libraries indicating that their connection speeds are insufficient all of the time (table 7); 20.3 percent of rural libraries, 29.5 percent of suburban libraries, and 30.0 percent of urban libraries indicating that their connection speeds are insufficient some of the time (table 8).

- Libraries that have ten or fewer workstations tend to rate their bandwidth as more sufficient at either $769 \mathrm{kbps}$ or less or greater than $769 \mathrm{kbps}$ (tables 7, 8, and 10).

Thus, in looking at the data, it is clear that libraries with fewer workstations indicate that their connection speeds are more sufficient to meet patron demand. 
Table 7. Public library connection speed insufficient to meet patron needs by metropolitan status

\begin{tabular}{|c|c|c|c|c|c|c|}
\hline & \multicolumn{2}{|c|}{ Rural } & \multicolumn{2}{|c|}{ Suburban } & \multicolumn{2}{|c|}{ Urban } \\
\hline $\begin{array}{l}10 \text { or fewer } \\
\text { workstations }\end{array}$ & $\begin{array}{l}25.4 \% \\
n=668\end{array}$ & $\begin{array}{l}12.1 \% \\
n=297\end{array}$ & $\begin{array}{l}27.4 \% \\
n=233\end{array}$ & $\begin{array}{l}9.8 \% \\
n=173\end{array}$ & $\begin{array}{l}15.4 \% \\
n=34\end{array}$ & $\begin{array}{l}10.2 \% \\
n=90\end{array}$ \\
\hline $\begin{array}{l}\text { More than } 10 \\
\text { workstations }\end{array}$ & $\begin{array}{l}11.6 \% \\
n=34\end{array}$ & $\begin{array}{l}11.4 \% \\
n=108\end{array}$ & $\begin{array}{l}19.2 \% \\
n=41\end{array}$ & $\begin{array}{l}11.3 \% \\
n=168\end{array}$ & $\begin{array}{l}25.4 \% \\
n=32\end{array}$ & $\begin{array}{l}17.1 \% \\
n=199\end{array}$ \\
\hline
\end{tabular}

Table 8. Public library connection speed insufficient to meet patron needs at some times by metropolitan status

\begin{tabular}{|c|c|c|c|c|c|c|}
\hline & \multicolumn{2}{|c|}{ Rural } & \multicolumn{2}{|c|}{ Suburban } & \multicolumn{2}{|c|}{ Urban } \\
\hline & LT769kbps & GT769KBPS & LT769kbps & GT769KBPS & LT769kbps & GT769KBPS \\
\hline $\begin{array}{l}10 \text { or fewer } \\
\text { workstations }\end{array}$ & $\begin{array}{l}34.1 \% \\
n=898\end{array}$ & $\begin{array}{l}19.3 \% \\
n=474\end{array}$ & $\begin{array}{l}37.1 \% \\
n=315\end{array}$ & $\begin{array}{l}29.0 \% \\
n=511\end{array}$ & $\begin{array}{l}50.0 \% \\
n=130\end{array}$ & $\begin{array}{l}27.0 \% \\
n=238\end{array}$ \\
\hline $\begin{array}{l}\text { More than } 10 \\
\text { workstations }\end{array}$ & $\begin{array}{l}43.2 \% \\
n=127\end{array}$ & $\begin{array}{l}22.5 \% \\
n=214\end{array}$ & $\begin{array}{l}42.3 \% \\
n=90\end{array}$ & $\begin{array}{l}30.3 \% \\
n=450\end{array}$ & $\begin{array}{l}60.3 \% \\
n=76\end{array}$ & $\begin{array}{l}32.0 \% \\
n=374\end{array}$ \\
\hline Total & $\begin{array}{l}35.0 \% \\
n=1,025\end{array}$ & $\begin{array}{l}20.3 \% \\
n=694\end{array}$ & $\begin{array}{l}38.1 \% \\
n=405\end{array}$ & $\begin{array}{l}29.5 \% \\
n=961\end{array}$ & $\begin{array}{l}53.4 \% \\
n=206\end{array}$ & $\begin{array}{l}30.0 \% \\
n=626\end{array}$ \\
\hline
\end{tabular}

Table 9. Public library connection speed is sufficient to meet patron needs by metropolitan status

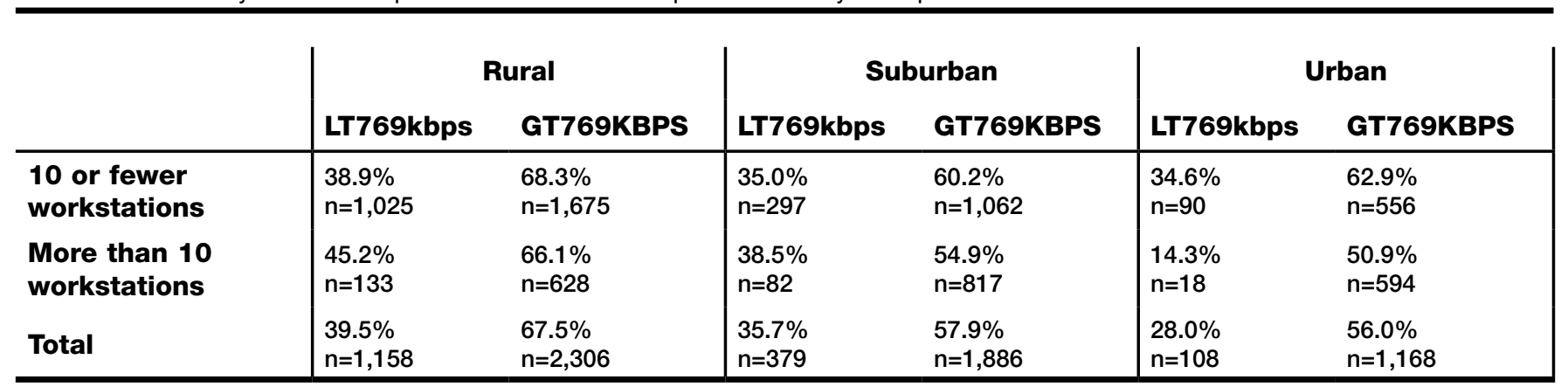

Table 10. Public library connection speed insufficient to meet patron needs some or all of the time by metropolitan status

\begin{tabular}{l|ll|ll|ll|}
\hline & \multicolumn{3}{|c|}{ Rural } & \multicolumn{2}{c}{ Suburban } & \multicolumn{2}{c}{ Urban } \\
& LT769kbps & GT769KBPS & LT769kbps & GT769KBPS & LT769kbps & GT769KBPS \\
\hline 10 or fewer & $59.5 \%$ & $31.4 \%$ & $64.6 \%$ & $38.8 \%$ & $65.4 \%$ & $37.1 \%$ \\
workstations & $n=1,566$ & $n=771$ & $n=549$ & $n=684$ & $n=170$ & $n=328$ \\
More than 10 & $54.8 \%$ & $33.9 \%$ & $61.5 \%$ & $41.6 \%$ & $85.7 \%$ & $49.1 \%$ \\
workstations & $n=161$ & $n=322$ & $n=131$ & $n=618$ & $n=108$ & $n=573$ \\
Total & $24.0 \%$ & $32.3 \%$ & $64.0 \%$ & $40.0 \%$ & $72.0 \%$ & $44.0 \%$ \\
\hline
\end{tabular}




\section{Discussion and selected issues}

The data presented point to a number of issues related to the current state of public library PAC and Internet-access adequacy in terms of available public access computers and bandwidth. The data also provide a foundation upon which to discuss the nature of quality and sufficient PAC and Internet access in a public library environment. While public libraries indicate increased ability to meet patron bandwidth demand when providing fewer publicly available workstations, public libraries indicate that they have difficulty in meeting patron demand for public access computers.

\section{Growth of wireless connections}

In $2004,17.9$ percent of public library outlets offered wireless access, and a further 21.0 percent planned to make it available. Outlets in urban and high-poverty areas were most likely to have wireless access. The majority of libraries (61.2 percent), however, neither had wireless access nor had plans to implement it in 2004. As table 11 demonstrates, the number of public library outlets offering wireless access has roughly doubled from 17.9 percent to 36.7 percent in two years. Furthermore, 23.1 percent of outlets that do not currently have it plan to add wireless access in the next year. Thus, if libraries follow through with their plans to add wireless access, 61.0 percent of public library outlets in the United States will have it by 2007.

The implications of the rapid growth of the public library's provision of wireless connectivity (as shown in table 11) on bandwidth requirements are significant. Either libraries added wireless capabilities through their current overall bandwidth, or they obtained additional bandwidth to support the increased demand created by the service. If the former, then wireless access created an even greater burden on an already problematic bandwidth capacity and may have actually reduced the overall quality of connectivity in the library. If the latter, libraries then had to shoulder the burden of increased expenditures for bandwidth. Either scenario required additional technology infrastructure, support, and expenditures.

\section{Sufficient and quality connections}

The notion of sufficient and quality public library connection to the Internet is a moving target and depends on a range of factors and local conditions. For purposes of discussion in this paper, the authors used $769 \mathrm{kbps}$ to differentiate "slower" from "faster" connectivity. If, however, $1.5 \mathrm{mbps}$ or greater had been used to define faster connectivity speeds, then only 28.9 percent of public libraries would meet the criterion of "faster" connectivity (see table 1). And in fact, simply because 28.9 percent of public libraries report connection speeds of $1.5 \mathrm{mbps}$ or faster does not also mean that they have sufficient or quality bandwidth to meet the computing needs of their users, their staff, their vendors, and their service providers. Some public libraries may need $10 \mathrm{mbps}$ to meet the PAC needs of their users as well as the internal staff and management computing needs.

The library community needs to become more educated and knowledgeable about what constitutes sufficient and quality connectivity in their library for the communities that they serve. A first step is to understand clearly the nature and type of the connectivity of the library. The next step is to conduct an internal audit that minimally:

- identifies the range of networked services the library provides both to users as well as for the operation of the library;

- identifies the typical bandwidth consumption of these services;

- determines the demands of users on the bandwidth in terms of services they use;

- determines peak bandwidth-usage times;

- identifies the impact of high-consumption networked services used at these peak-usage times;

- anticipates bandwidth demands of newer services and resources that users will want to access through the library's infrastructure-Myspace.com, YouTube. com-regardless of whether or not the library is the direct provider of such services; and

- determines what broadband services are available to the library, the costs of these services, and the "fit" of these services to the needs of the library.

Based on this and related information from such an audit, library administration can better determine the degree to which the bandwidth is sufficient in speed and quality.

\section{Planning for sufficient and quality bandwidth}

Knowing the current condition of existing bandwidth in the library is not the same as successful technology planning and management to ensure that the library has, in fact, bandwidth that is sufficient in speed and quality. Once an audit such as has been suggested is completed, careful planning for bandwidth deployment in the library is essential. It appears, however, that currently much of the management and planning for networked services is based first on what bandwidth is available as opposed to the bandwidth that is needed to provide the necessary services and resources in a networked environment. This stance puts public libraries in a reactive condition rather than a proactive condition regarding provision of networked services. 
Table 11. Public-access wireless Internet connectivity availability in public library outlets by metropolitan status and poverty

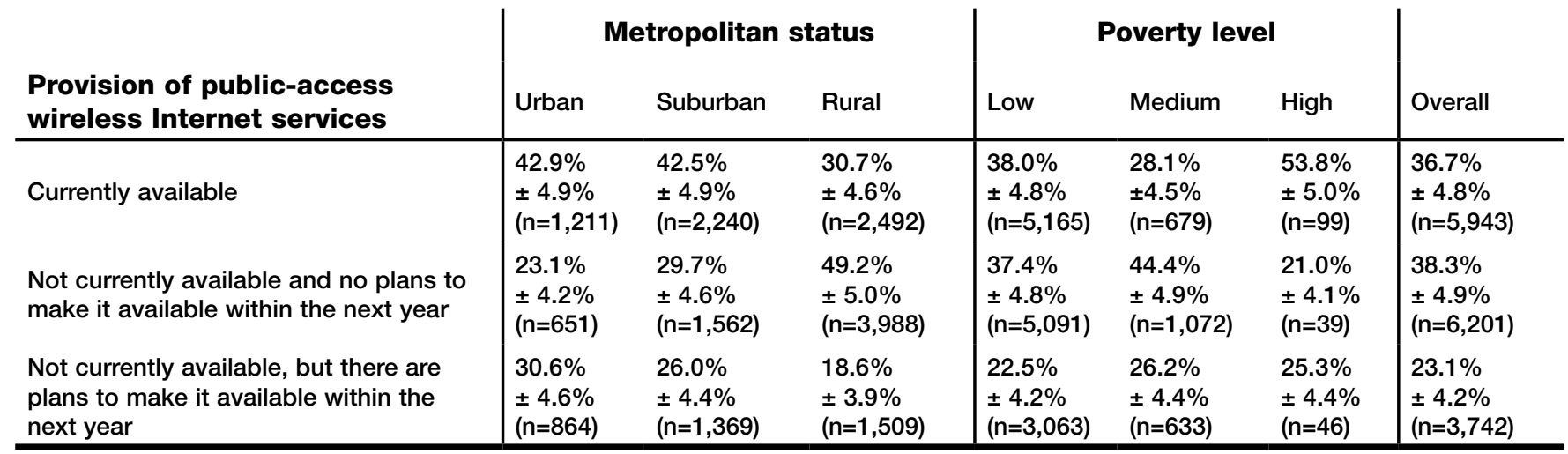

Most public library planning approaches stress the importance of conducting some type of needs assessment as a precursor to any type of planning. ${ }^{5}$ Further, technology plans should include such things as goals, objectives, services provision, and evaluation as they relate to bandwidth and the appropriate bandwidth needed. Recent library technology planning guides, however, give little attention to the management, planning, and evaluation of bandwidth as it relates to provision of networked services.

It must be noted that some public libraries may be prevented from accessing higher bandwidth due to high cost, lack of availability of bandwidth alternatives, or other local factors that determine access to advanced telecommunications in their areas. In such circumstances, the audit may serve to inform the public service/utilities commissions, FCC, and others of the need for deployment of advanced telecommunications services in these areas.

\section{Bandwidth planning in a community context}

The audit and planning processes that have been described are critical activities for libraries. It is essential, however, for these processes to occur in the larger community context. Investments in technology infrastructure are increasingly a community-wide resource that services multiple functions-emergency services, community access, local government agencies, to name a few. It is in this larger context that library PAC and Internet access occurs. Moreover, there is a convergence of technology and service needs. For example, public libraries increasingly serve as agents of e-government and disaster-relief providers. ${ }^{6}$ First responders rely on the library's infrastructure when theirs is destroyed, as Hurricane Katrina and other storms demonstrated. Local, state, and federal government agencies rely on broadband and PAC and Internet access (wired or wireless) to deliver e-government services.

Thus, at their core, libraries, emergency services, government agencies, and others have similar needs. Pooling resources, planning jointly, and looking across needs may yield economies of scale, better service, and a more robust community technology infrastructure. Emergency providers need access to reliable broadband and communications technologies in general, and in emergency situations in particular. Libraries need access to high-quality broadband and PAC technologies. Both need access to wireless technologies.

As broadcast networks relinquish ownership of the $700 \mathrm{MHz}$ frequency used for analog television in February 2009, and this frequency is distributed to municipalities for emergency services, now is an excellent time for libraries to engage in community technology planning for e-government, disaster planning and relief efforts, and PAC and Internet services. By working with the larger community to build a technology infrastructure, the library and the entire community benefit.

\section{Availability to high-speed connectivity}

One key consideration not known at this time is the extent to which public libraries-particularly those in rural areas-even have access to high-speed connections. Many rural communities are served not by the large telecommunications carriers, but rather by small, privately owned-and-run local exchange carriers. Iowa and Wisconsin, for example, are each served by more than eighty exchange carriers. As such, public libraries are limited in capacity and services to what these exchange 
carriers offer and make available. Thus, in some areas, DSL service may be the only form of high-speed connectivity available to libraries. And, as suggested earlier, DSL may or may not be considered high speed given the needs of the library and the demands of its users.

Communities that lack high-quality broadband services by telecommunications carriers may want to consider building a municipal wireless network that meets the community's broadband needs for emergency, disaster, and public-access settings. As a community engages in community-wide technology planning, it may become evident that local telecommunications carriers do not meet the broadband needs of the community. Such communities may need to build their own networks, based on identified technology-plan needs.

\section{Knowledge of networked services connectivity needs}

Patrons may not attempt to use high-bandwidth services at the public library because they know from previous visits that the library cannot provide acceptable connectivity speeds to access that service-thus, they quit trying to access that service, limiting the usefulness of the public library. In addition, librarians may have inadequate knowledge or information to determine when bandwidth is or is not sufficient to meet the demands of their users. Indeed, the survey and site visits revealed that some librarians did not know the connection speeds that linked their library to the Internet.

Consequently, libraries are in a dilemma: increase both the number of workstations and the bandwidth to meet demand; or provide less service in order to operate within the constraints of current connectivity infrastructure. And yet, roughly 45 percent of public libraries indicate that they have no plans to add workstations within the next two years; the average number of workstations has been around ten for the last three surveys (2002, 2004, and 2006); and 80 percent of public libraries indicate that space limitations affect their ability to add workstations. ${ }^{7}$ Hence, for many libraries, adding workstations is not an option.

\section{Missing the mark?}

The networked environment is such that there are multiple uses of bandwidth within the same library-for example, public Internet access, staff access, wireless access, integrated library system access. We are now in the Web 2.0 environment, which is an interactive Web that allows for content uploading by users (e.g., blogs, Mytube.com, Myspace.com, gaming). Streaming content, not text, is increasingly the norm. There are portable devices that allow for text, video, and voice messaging. Increasingly, users desire and prefer wireless services.

This is a new environment in which libraries provide public access to networked services and resources. It is an enabling environment that puts users fully in the content seat-from creation to design to organization to access to consumption. And users have choices, of which the public library is only one, regarding the information they choose to access. It is an environment of competition, advanced applications, bandwidth intensity, and high-quality computers necessary to access the graphically intense content.

The impacts of this new and substantially more complex environment on libraries are potentially significant. As user expectations rise, combined with the provision of high-quality services by other providers, libraries are in a competitive and service- and resource-rich information environment. Providing "bare minimum" PAC and Internet access can have two detrimental effects in that they: (1) relegate libraries to places of last resort, and (2) further digitally divide those who only have public-access computers and Internet access through their public libraries. It is critical, therefore, for libraries to chart a high-end course regarding PAC and Internet access, and not access that is merely perceived to be acceptable by the librarians.

\section{Additional research}

The context in which issues regarding quality PAC and sufficient connectivity speeds to Internet access reside is complex and rapidly changing. Research questions to explore include:

- Is it possible to define quality PAC and Internet access in a public library context?

- If so, what are the attributes included in the definition?

- Can these attributes be operationalized and measured?

- Assuming measurable results, what strategies can the library, policy, research, and other interested communities employ to impact public library movement toward quality PAC and Internet access?

- Should there be standards for sufficient connectivity and quality PAC in public libraries?

- How can public librarians be better informed regarding the planning and deployment of sufficient and quality bandwidth?

- What is the role of federal and state governments in supporting adequate bandwidth deployment for public libraries? ${ }^{8}$

- To what extent is broadband deployment and availability truly universal as per the Universal Service 
(section 254) of the Telecommunications Act of 1996 (P.L. 104-104)?

These questions are a beginning point to a larger set of activities that need to occur in the research, practitioner, and policy-making communities.

\section{Obtaining sufficient and quality public-library bandwidth}

Arbitrary connectivity speed targets, e.g., 200kbps or $769 \mathrm{kbps}$, do not in and of themselves ensure quality PAC and sufficient connectivity speeds. Public libraries are indeed connected to the Internet and do provide publicaccess services and resources. It is time to move beyond connectivity-type and -speed questions and consider issues of bandwidth sufficiency, quality, and the range of networked services that should be available to the public from public libraries.

Given the widespread connectivity now provided from most public libraries, there continue to be increased demands for more and better networked services. These demands come from governments that expect public libraries to support a range of e-government services, from residents who want to use free wireless connectivity from the public library, to patrons who need to download music or view streaming videos (to name but a few). Simply providing more or better connectivity will not, in and of itself, address all of these diverse service needs.

Increasingly, PAC support will require additional public librarian knowledge, resources, and services. Sufficient and quality bandwidth is a key component of those services. The degree to which public libraries can provide such enhanced networked services (requiring exceptionally high bandwidth that is both sufficient and of high quality) is unclear. Mounting a significant effort now to better understand existing bandwidth use and plan for future needs and requirements in individual public libraries is essential. In today's networked envi- ronment, libraries must stay competitive in the provision of networked services. Such will require sufficient and high-quality connectivity and bandwidth.

\section{Acknowledgements}

The authors gratefully acknowledge the support of the Bill \& Melinda Gates Foundation and the American Library Association for support of the 2006 Public Libraries and the Internet Study. Data from that study have been incorporated into this paper.

\section{References}

1. Information Institute, Public Libraries and the Internet (Tallahassee, Fla.: Information Use Management and Policy Institute, 2006). All studies conducted since 1994 are available at: http:/ / www.ii.fsu.edu/plinternet (accessed March 1, 2007).

2. U.S. Federal Communications Commission, High Speed Services for Internet Access: Status as of December 31, 2005 (Washington, D.C.: FCC, 2006), available at http://www.fcc.gov/ Bureaus/Common_Carrier/Reports/FCC-State_Link/IAD/ hspd0604.pdf (accessed Mar. 1, 2007).

3. J. C. Bertot et al., Public Libraries and the Internet 2006 (Tallahassee, Fla.: Information Use Management and Policy Institute, forthcoming), available at http://www.ii.fsu.edu/plinternet (accessed Mar. 1, 2007).

4. J. C. Bertot et al., "DRAFTED: I Want You to Deliver EGovernment," Library Journal 131, no. 13 (Aug. 2006): 34-37.

5. C. R. McClure et al., Planning and Role Setting for Public Libraries: A Manual of Options and Procedures (Chicago: ALA, 1987); E. Himmel and W. J. Wilson, Planning for Results: A Public Library Transformation Process (Chicago, ALA, 1997).

6. J. C. Bertot et al., "DRAFTED: I Want You to Deliver E-Government."; P. T. Jaeger et al., "The Policy Implications of Internet Connectivity in Public Libraries," Government Information Quarterly 23, no. 1 (2006): 123-41.

7. J. C. Bertot et al., Public Libraries and the Internet 2006.

8. Jaeger et al., "The Policy Implications of Internet Connectivity in Public Libraries." 